\title{
Twins in cryolite types from Ivigtut, South Greenland
}

HANS PAULY

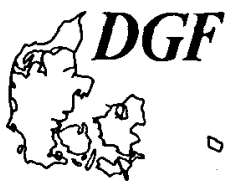

Pauly, Hans: Twins in cryolite types from Ivigtut, South Greenland. Bull. geol. Soc. Denmark, vol. 27, Special Issue,: pp. 7-14, Copenhagen, July 30th 1978. https://doi.org/10.37570/bgsd-1978-SI-02

The appearance of twins in various coarse grained types of cryolite from Ivigtut is illustrated. The examina-tion is based on large thin sections (from $5 \mathrm{~cm}$ to $12 \mathrm{~cm}$ across) of pure, white large-grained cryolite, similar large-grained cryolite from fluorspar-cryolite and from a vein of pure, black cryolite in the wallrocks. The seven twin laws identified by Bøggild $(1911,1912)$ were found in most samples. The sample from fluorite- cryolite was dominated by the twin law (001) and the sample from the vein was dominated by [021] ${ }^{120}$. The general picture seems to favour a mechanical formation of all twins in the samples. The characteristic parting of cryolite is intimately related to the presence of twin lamellae, mainly as reported by Bøggild (1911, 1912), corresponding to the law [021] ${ }^{120}$ but also (110) (Bøggild 1913), and (001) as observed in the sample from fluorite-cryolite here examined. This sample also contains indications for several stages of reorienta-tion presumably in response to outside stress situations.

Hans Pauly, Mineralogical Institute, Technical University of Denmark, DK-2800, Lyngby, Denmark. January 10th, 1978.

In the pure, very large-grained cryolite from Ivigtut 7 twin laws can be distinguished (Bøggild 1911 $\& 1912)$. The possible twin laws in the polysynthetic, mimetic cubic edifice of cryolite appear from an evaluation of all cubic symmetry elements, (Bøggild 1912). Thirteen twin laws are predicted by theory and the twin operations are the operations of pseudo-symmetry of a quasi-cubic double cell obtained from the cryolite cell by transformation 110/110/001, (Donnay 1952).

The thirteen twin laws are:

\begin{tabular}{|l|lc|c|cc|c|cc|}
\hline & Twl & Cp | & TwL & Tp & TwL & Cp \\
\hline 1 & {$[110]^{90}$} & $(112)$ & 5 & $(001)$ & $(001)$ & 10 & {$[111]$} & $(110)$ \\
2 & {$[110]$} & $(110)$ & 6 & $(100)$ & $(100)$ & 11 & {$[001]^{90}$} & $(110)$ \\
3 & {$[021]^{120}$} & $(110)$ & 7 & $(112)$ & $(112)$ & 12 & {$[201]^{120}$} & $(\overline{1} 12)$ \\
4 & {$[\overline{1} 11]$} & $(110)$ & 8 & $(\overline{1} 12)$ & $(\overline{1} 12)$ & 13 & {$[\overline{201}]^{120}$} & $(112)$ \\
& & & 9 & $(110)$ & $(110)$ & & & \\
\hline
\end{tabular}

$\mathrm{TwL}=\mathrm{Twin}$ Law; $\mathrm{Cp}=$ Composition plane; $\mathrm{Tp}=\mathrm{T}$ win plane

Of these laws 1-4 were found in crystals, 1-3 and 5-8 in the pure, very large-grained cryolite from Ivigtut, 9 only in cryolite from Ural (Bøggild 1913). The laws 11,12 and 13 can not be distinguished optically from 9,8 and 7 respectively, (Bøggild 1911 \& 1912). Here he noted that 10 has not been found although it might occur. $\mathrm{He}$ commented upon the fact that only 1-4 have been seen in crystals where 5-9 do not occur. In the crystals, laws no. 1, 2 (in some cases) and 4 are regarded as growth twins whereas no. 3 is secondary (Bøggild 1911 \& 1912).

The presence of twins reflects features in the formation of the twinned material. The crystals of cryolite lined open cracks and formed through precipitation from circulating water at low temperature $\left(100^{\circ} \mathrm{C}\right.$ or less?). The pure, very largegrained cryolite occured as a $150 \times 60 \times 20 \mathrm{~m}^{3}$ body in the lower western part of the cryolite mass which mainly consisted of siderite cryolite. Sweeping around the $\mathrm{S}$ and $\mathrm{W}$ sides of the pure cryolite occurred cryolite containing varying amounts of fluorite, topaz, "ivigtite" (finegrained K-mica), chiolite, weberite, jarlite etc. This heterogeneous material is termed fluorite-cryolite. Just as the siderite cryolite it may be subdivided into classes according to cryolite content. In the rich classes cryolite occurred in dm sized grains.

Formation temperature for siderite cryolite is thought to range from well over $500^{\circ} \mathrm{C}$ to around $400^{\circ}$, (Oen \& Pauly 1967). Fluorite cryolite formed later, brecciation and replacement characterise the boundaries between the two types of cryolite, and consolidation temperatures are believed to be around $300^{\circ} \mathrm{C}-200^{\circ}$, (Karup-Møller \& Pauly in press). Together with the complicated processes at work during the formation, mechanical forces giving rise to plastic deformation also influenced the cryolite at many stages of the formation. 
In order to get an idea of the extent to which examination of twins in cryolite might reveal features from the formation story, large thin sections of various cryolite types were produced and studied. The optical properties of cryolite (Pauly 1977) and the complicated nature of the twin laws make it difficult to identify the twins unless the thin section has a simple crystallographic orientation. Moreover, it is noted that sections should have thicknesses of ca. $100 \mu \mathrm{m}$ because of the very low birefringence of the mineral.

Suitable material could be obtained from samples of the pure, very large-grained cryolite. Of this material 14 large thin sections were produced from 6 different samples plus 6 sections of drillingcores in the same material. Fluorite cryolite with dm-sized cryolite grains yielded $4 \mathrm{sec}$ tions from 2 samples and a vein of pure cryolite allowed oriented sections in 3 directions.

\section{Pure, very large-grained cryolite}

Bøggild (1905) reported extremely large individuals of cryolite in this material, up to $6 \mathrm{~m}$. This material often shows good parting along (110) and weak parting along (001) (Bøggild 1911 \& 1912). It is penetrated by a close network of twin lamellae (Bøggild 1953). The recognition of the metre-sized individuals was based on just these two phenomena. In the present work they also served as means for the orientation of the sections. Thin sections parallel to the good parting faces were found to correspond to the two prism faces (110) and (1 $\overline{1} 0)$. The section perpendicular to these sections came out as a $(001)$ face. The block was finally cut parallel to (010) and this was also the orientation characterising the section produced. A picture of the 3 sections (110), (110) and $(001)$ viewed between crossed polars is given in fig. 1. The choice of crystallographic orientation was based upon orientation of twin lamellae in (001) and extinction angles in the (010) section.

The prism faces are characterised through vertical zones of lamellae. Although many lamellae are less than $0.1 \mathrm{~mm}$ they can be followed through the full length of the section. Whereas (110) has numerous shorter lamellae inclined at an angle of $45^{\circ}$, the (110) section shows numerous (slightly inclined) horizontal lamellae.

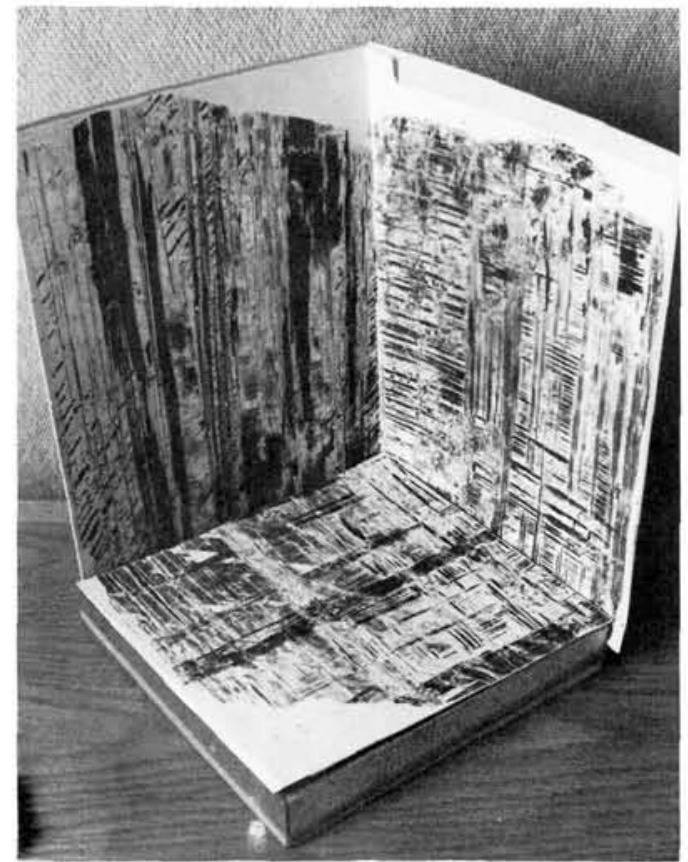

Fig. 1. Photos of thin sections of white cryolite between + polars (used as photographic negatives). The photos of the 3 sections (110), (170) and (001) mounted in their proper position illustrate interrelations of twin lamellae. The edge of the square (001) section is $5.5 \mathrm{~cm}$.

The (010) section resembles the prism sections in having vertical zones of lamellae in the full length of the section. It is moreover characterised by systems of inclined lamellae having angles around $55^{\circ}$ to the right and left of the vertical. The one system is found to dominate (Pauly 1977, fig. 1).

The section (001) (fig. 2) is very characteristically transsected by lamellae and zones of lamellae in two directions perpendicular to each other. Due to slight tilting of the section between the crossed polars, zones of lamellae at $45^{\circ}$ to the mentioned zones are also seen.

Determinations of extinction angles, in some cases supplemented by observations of conoscopic interference figures form the basis for the identification of the twin laws in these crystallographically oriented sections (cf. Bøggild 1911 \& 1912).

In section (110) a few dark cm-wide zones can be seen. They correspond to parts of the cryolite block oriented according to the (100) twin law relative to the light coloured main part of the section. These (100) twins are represented by the 


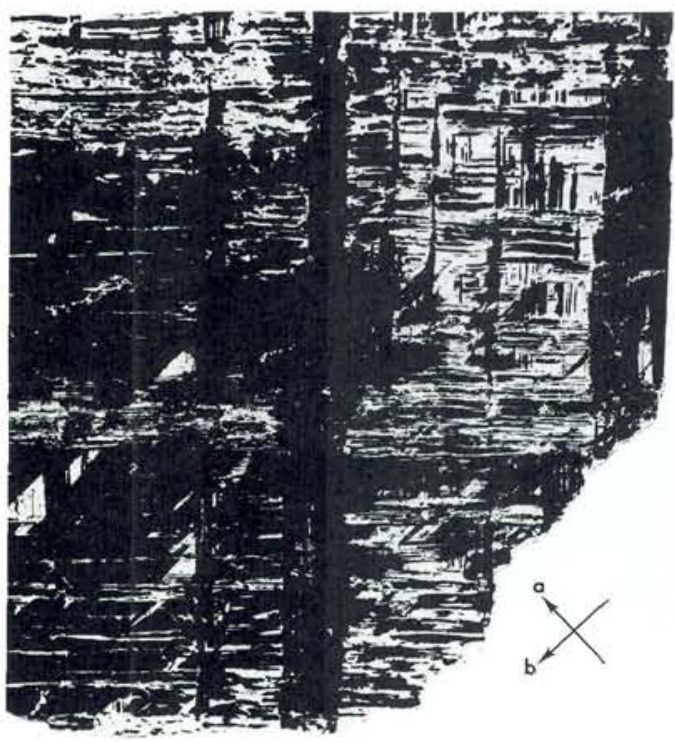

Fig. 2. Magnified picture of the (001) section fig. I, illustrating the various twin laws: $[021]^{120}$ in the broad zones, $[110]$ the numerous thin lamellae and (100) the $45^{\circ}$ inclined zones. Note the bending of lamellae and the mutual overlap of twin formation. Edge of square $5.5 \mathrm{~cm}$.

zones making $45^{\circ}$ with the main zones in the (001) section (fig. 2). The position of the crystallographic b-axis is given by these (100) twins in this section.

Along the centreline of section (110) (fig. 1) a system of closely spaced lamellae can be seen. They have been produced by the twin law observed by Bøggild (1911 \& 1912) which has been reformulated by Donnay (1952) as a twin according to $[021]^{120}$ i.e. with a $120^{\circ}$ turn. In prism sections these lamellae alternatingly show (110) and (001) orientations, the extinctions thus shift between $30^{\circ}$ and $45^{\circ}$.

Higher magnification reveals the presence of narrow, straight lamellae corresponding to twins according to [110] (fig. 3). In section (001) these lamellae have simultaneous extinction but $\alpha$ in one lamella is found to be at right angles to $\alpha$ in the next lamella.

The $45^{\circ}$ inclined lamellae in (110) are parallel to (112) and this is the twin plane for these lamellae. Microscopic examination reveals the presence of just as many lamellae having the same direction but being twin oriented according to the so-called Baumhauer Law i.e. $[110]^{90}$.

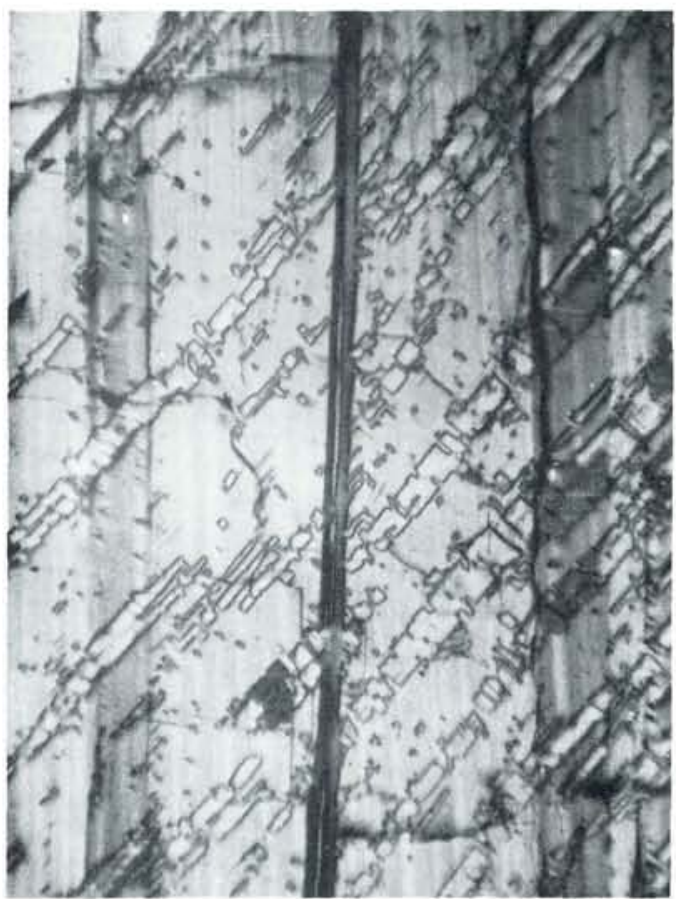

Fig. 3. Microphot, of lower right corner of (110) section, fig. $I$. Magn. $33 x$, + polars. Twin law $[110]^{\text {wo }}$ appears as "hacked" lamellae. Dark portions of these lamellae are however twins according to (112), see left side of photo. Thin, faintly visible lamellae are twins according to [110]. Nearly black lamellae are $[02 J]^{120}$ twins.

Lamellae following ( 112$)$ produce in sections along $(1 \overline{1} 0)$ horizontal lamellae. The $(010)$ section shows that similar lamellae with the opposite inclination are also present. This indicates the existence of the twin law (112) and of Baumhauer lamellae parallel to this plane.

The observed twins in this block of pure cryolite correspond clearly to the observations of Bøggild (1911, 1912). It should, however, be noted that the twin law (001) is not to be seen in the pictures. Only in a few cases has this law been found in the sections from this block, and in these cases it related two parts of a vertical lamella with each other.

The persistence of the twin lamellae is remarkable, underlining the macroscopic nature of these twin formations. The metre sized individuals in this type of cryolite, as mentioned, were recognized due to these phenomena, further underlining the big scale of these twins. 
Apart from slight deviations of the orientation of the sections, it lies in the nature of the twins that the lamellae produced do not exactly follow crystallographic directions. This is clearly seen in the section $(1 \overline{1} 0)$ where the horizontal (112) lamellae deviate several degrees from being perpendicular to the vertical lamellae. Between vertical lamellae due to [110] twinning and vertical lamellae due to $[021]^{120}$ twinning, similar angular deviations are noted $\left(3^{\circ}\right.$ to $\left.4^{\circ}\right)$. Lamellae of the first of these laws are narrow, straight, and have parallel borders, whereas lamellae belonging to the other law usually are less sharp and their borders are slightly curving. It is, however, clearly seen that [110] lamellae are discordant against the lamellae to the $[021]^{120}$ law (much like crossbedding in bedded sandstone).

The appearance of the [110] twin lamellae as narrow, straight lamellae makes them easy to recognize. They were found in all sections studied and they correspond closely to the picture Bøggild (1911 \& 1912) gives (fig. 7, in his first plate). Verification of their nature through optical determinations, however, is difficult. In sections along (001), as mentioned, they may be identified

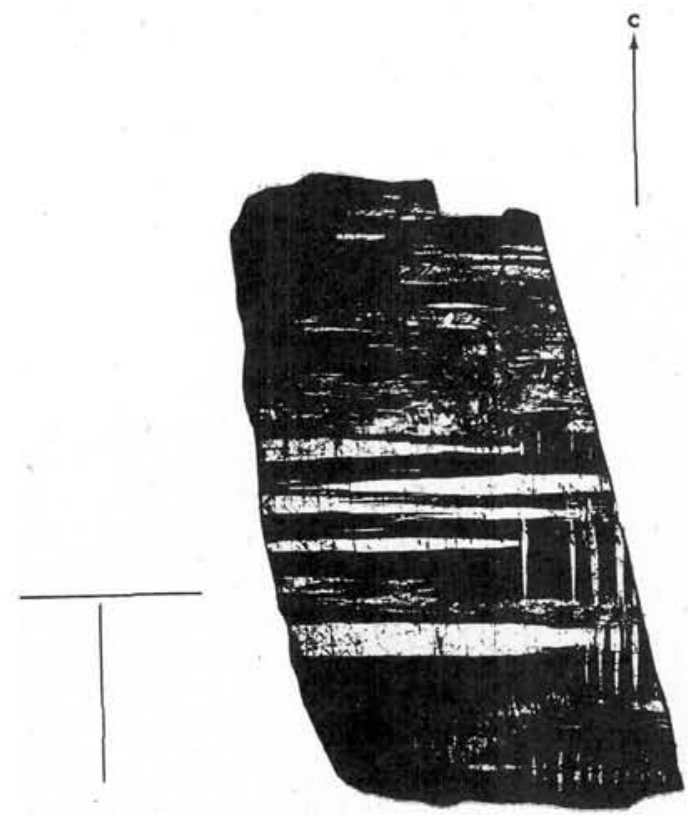

Fig. 4. Photo of thin section, nat. size, + polars, of block of white cryolite cut along (110). Twin lamellae according to (001) are broad, horisontal. Spindle shaped, vertical lamellae are twinned according to (100). Other twin laws are also present, thus in middle left a thin (112) lamella can be seen. through the position of " $\alpha$ ". But here it is also noted that every other lamellae is much thinner than its neighbours. In prism sections this, together with the inclined direction of the border between pairs of lamellae, may prevent observation of lamellae from both individuals of the twin. Rather often, however, one gets the impression that only one individual is present. If these twins were established early in the history of the material, and recrystallisation caused the obliteration of the one individual, only leaving impuritydecorated traces of the original boundaries, then it would be easy to understand that groups of such lamellae give nice coherent interference figures in conoscopic observations (single lamellae in most cases are too narrow for such examinations but, where it has been possible, neighbouring lamellae gave identical flashfigures).

The picture of the section (001) (fig. 2) clearly shows age relations between zones of twin lamellae. The dark zone is seen to be displaced and broken up by the crossing light coloured zone. On closer inspection lamellae are also seen to follow wavy courses. The mechanical nature of these twins is clear and obviously the twins in the light coloured zone formed later than those in the dark zone. It should be noted that these two zones represent twins according to the $[021]^{120}$ twin law.

Within lamellae belonging to this law one can often find twin lamellae from (112) twins and Baumhauer twins as is shown in the microphoto fig. 3 .

In fig. 4 a large thin section of another block shows the appearance of twin lamellae according to the (100) law together with the (001) law. The other 5 twin laws were also found in this section.

Thin sections from 3 drillcores from vertical borings through the mass of pure cryolite were also examined. All above mentioned twins seem to be present. Detailed identification is difficult, however, because the sections were not crystallographically oriented. The sections were made in order to see if specific orientation could be found in cryolite "in situ". This is still an open question. In order to answer it additional samples are needed and obviously also a number of sections along drill cores in order to clear up local deviations.

Twin lamellae corresponding closely to those present in the block of pure cryolite here treated 
in detail, were observed in another block sectioned in connexion with determinations of optical data for cryolite (Pauly 1977).

\section{Cryolite from a vein}

Fig. 5 shows the peculiar development of twin lamellae in cryolite from a vein in the rocks surrounding the cryolite body. It occurred at the edge of the quarry in the NW corner, some $20 \mathrm{~m}$ from the cryolite body, close the remnants of the pegmatite, see Bøggild (1953) and Pauly (1974).
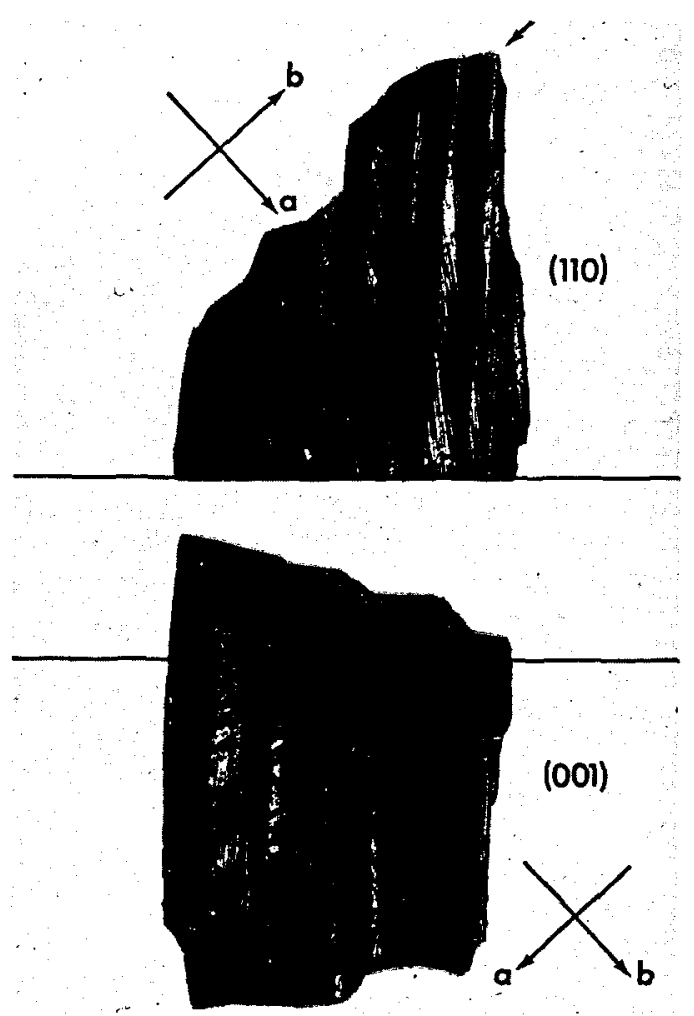

Fig. 5. Thin sections, (110) and (00I), nat. size, + polars, of black cryolite from a vein. In (00I) most lamellae are parallel, slightly curving. Lamellae in (110) constitute two systems of alternating zones. In every other zone one notes that the lamellae make an angle $\left(12^{\circ}-14^{\circ}\right)$ with the zone direction. Most lamellae belong to twins after $[021]^{120}$ in both sections. The arrow, top corner of section (110), points to lamellae representing (100) twins. Inclined $\left(45^{\circ}\right)$ lamellae in section (001) are mainly (112) twins but $[110]^{90}$ are also present. In this position relative to polars (100) twins present cannot be seen in section (001).
Rather strong radioactive mineralisations (a Thsilicate was present among other minerals) was registered close to the cryolite vein in which the cryolite was pitch black, presumably due to the irradiation.

In contrast to the pure white cryolite the samples from the vein showed very pronounced parting parallel to one plane. Apart from the black colour the appearance is much like cleavage fragments of gypsum. A weak parting perpendicular to the strong parting is also seen. Thin sections parallel to the partings and one perpendicular to them were produced. Optical studies showed the sections to follow the prism faces (110), (1T0) and the base (001). The section along the strong parting was less useful but the two other sections shown in fig. 5 clearly revealed the nature of this sample.

Twin laws observed are: $[021]^{120},[110],[110]^{90}$, [112], [112] and (100). Concerning the third, fourth and fifth: lamellae following (112) are well represented whereas the opposite direction is rare. However, the sections are dominated by $[021]^{120}$, which means a shift of orientation between (110) and (001). The $45^{\circ}$ inclined lamellae are thus either (112) or (100) depending upon the orientation of the lamellae in question. Both twins are found in both sections. The section with parallel lamellae has been chosen as the basis (001) and the direction of $(100)$ twin lamellae combined with optical orientation of the cryolite have determined the orientation of the crystallographic axes.

The most impressive feature of the cryolite from the vein is the discordance between lamellae in every other zone of the section chosen as (110). The prominent parting follows the direction of the zones. The angle between the discordant lamellae and the zone direction, or the direction of the concordant lamellae in the other set of zones, lies between $12^{\circ}$ and $14^{\circ}$. The direction of the inclined lamellae is close to the plane $(2 \overline{2} \overline{1})$ with the chosen orientation. An interchange of the crystallographic orientation of the sections would result in the plane (230) as direction for the inclined lamellae. However, it seems less probable that a definite crystallographic direction should be attributed. The phenomenon may rather be taken as an expression of lamellar translation accompanied by a reorientation of the involved material. The prominent parting and the concordant lamellae represent the reoriented part of the cryolite from this vein. The width of the 
vein was not much more than the size of the samples i.e. a dm or two. Similar veins have been observed in the walls of the quarry where they were seen to have lengths of many metres. It is to be regretted that the orientation of the sample in the vein was not noted, but at that time study of the occurence of this type of phenomenon was not contemplated. Examination of the samples, collected 15 years ago, gives just a feeling that parting faces were perpendicular to the elongation of the vein. If this is correct the (001) should then have been parallel to the walls of the vein.

\section{Cryolite with crystal faces, from fluorite-cryolite}

During inspection of newly mined fluorite-cryolite (in 1961), a metre-sized block was found to contain large individuals of cryolite showing nice, plane surfaces partly coated by thin films of topaz and/or ivigtite (the characteristic yellow-greenish $\mathrm{K}$-mica associated with this type of cryolite raw material). Four such cryolite lumps were knocked out of the block. Two of them have enough plane faces as to look like cubes modified by the octahedra. The plane faces are 2 to $4 \mathrm{~cm}$ across on the one sample and 5 to $8 \mathrm{~cm}$ on the other sample.

On these samples the striation from twin lamellae gives prominence to just one plane which is also parallel to a parting face. A thin section along this plane was made and it came out as (001), then two more sections were produced parallel to (110) and (010).

The optically determined generel orientation of the material showed the plane faces on this piece of cryolite to correspond to (001), (101) and (011). The section (001) also contains traces of a plane sheet of topaz which has angular relations to the rest of the block, showing that it also can be interpreted as a layer parallel to (101). This topaz layer cuts the $(001)$ section and together with the (100) twin lamellae in this section it defines the direction of the $b$-axis.

The seven twin laws found in the pure, largegrained cryolite are also present in this material but (001) dominate absolutely as closely spaced, thin but long lamellae running in the full width of the sections (110) and (010) fig. 6. The boundaries of these lamellae, however, are curving and somewhat irregular. The [110] twin lamellae are seen in most parts of the sections as the usual straight, narrow lamellae and in many areas (112) appear as shorter, thin lamellae especially noted in section (010). Twin lamellae after (100) are rare but distinct in the section (001).

Although [110] lamellae are often traceable all through the sections it is noted that they show changes of direction, either abrupt or due to curvatures. Deviations may amount to about $7^{\circ}$ when directions are compared in both ends of the section (010). Similar deviations are found when (112) lamellae are compared from different areas of the section, deviations for these lamellae reach $4^{\circ}$ in the section (010). Also, (001) lamellae show such deviations, up to $9^{\circ}$.

The picture is somewhat blurred through the presence in larger parts of the sections (especially (010) and (001)) of irregular cloud-like areas, rather elongated, which seem to have mainly lamellae according to [110] but so to say belonging to themselves. A liberal interpretation of these elongated cloudy areas might indicate similarities with (112) oriented lamellae, from their attitude.

The optical character of the sections is marked by more or less pronounced wavy extinction.

An astonishingly clear feature in the sections (010) and (110), however, is the presence of sharp or rather sharp linear "traces" cutting through most of the sections - indicated on fig. 6. The sharp trace on (010), together with two traces which microscopically are seen to consist of stringers of tiny rounded cryolite grains (with their own orientation of twin lamellae), forms an exact rectangle: the traces are perpendicular to each other within a degree (or less). The inclination of these traces in the (110) section shows them to represent $(11 \overline{2})$ and (101). The latter plane with which the stringers of rounded cryolite grains correspond was also the plane which the topaz layer was found to match. The plane faces found on the cryolite fit the crystallographic orientation determined through the traces.

It is difficult to imagine the formation of the plane faces and the traces seen in the sections, in the disorganised crystallographic buildup of the present material with $4^{\circ}-9^{\circ}$ deviations. One might therefore regard the plane faces and the "traces" 


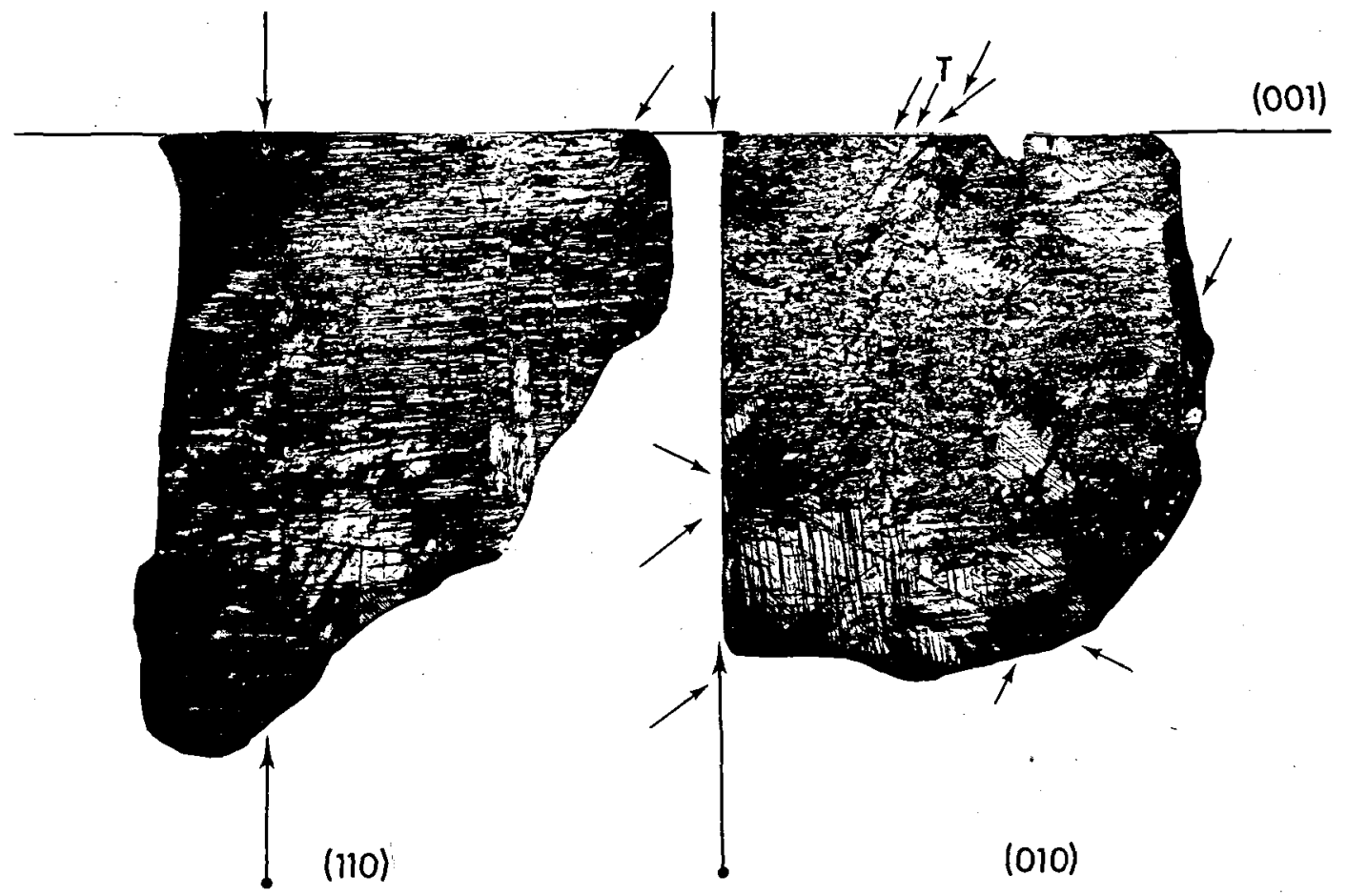

Fig. 6. Thin sections (110) and (010), nat. size, + polars, cryolite from fluorite-cryolite. The upper edge of both sections represent the trace of (001). The bold arrows indicate in section (110) the trace of section (010) i.e. the left straight-lined edge

as having been formed at an earlier stage, when the whole mass was crystallographically homogeneous. Later events caused the cryolite to readjust to outside stresses but did not obliterate the original orientation of the other phenomena. This may be accepted for the topaz layer decorating a plane along (101) and the topaz and/or "ivigtite" decorated plane faces of this cryolite. It is less evident for the traces that are represented by stringers of rounded cryolite grains. Neither is it easy to accept for the traces following (112), unless one might regard specifically this direction and the corresponding orientation of the cryolite within this trace as well adapted to the later stress directions.

\section{Parting and fracture in cryolite}

Bøggild (1911 \& 1912) stated that cryolite has no cleavage but shows parting along (110). He noted that the parting seems to be related to twin la- of (110). Twins after (001) dominate. In (010) can also be seen [110] twins and systems of (112) twin lamellae. Thin arrows indicate traces of (101) in (110) and (010) and further (in section (010)) traces of (115) and of the topaz layer (T).

mellae due to the law [021 ${ }^{120}$. This he concluded from examination of cryolite crystals. Concerning pure large-grained cryolite he stated that parting follows the faces of the apparent cube. In his discussion of twins in the pure large-grained cryolite, he mentioned the observation that parting along the prism faces is more pronounced than that along (001).

Parting along (110) due to twin lamellae according to the law (110) was observed in cryolite from Ural, (Bøggild 1913).

The (001) parting in the common samples of cryolite was not related to twin lamellae by Bøggild. This is also what the present examination seems to indicate. One may well expect that samples containing a fair amount of twin lamellae after $[021]^{120}$, which is shifting the position of the prism faces into that of the base, would give possibilities for the cube-like parting. Examining the large thin sections in suitable oblique illumination, systems of cracks are observed. Apart from those connected with the prismatic parting, 
traversing the section where traversing twin lamellae are present, one observes numerous short cracks perpendicular to the long twin lamellae. The length of these cracks is usually determined by the width of the lamella; they may cross one or two neighbouring lamellae but mostly these cracks convey to the lamella the appearance of a ladder, the cracks looking like the steps of the ladder. Usually neighbouring lamellae show their "ladder steps" to be out of phase. These cracks may however be so closely spaced that one may expect them to represent a fair fracture surface following (001). In the thin sections of cryolite with crystal faces, from fluorite cryolite, (001) was the dominating twin law. Here it was observed that numerous cracks were developed following these lamellae.

In a (001) section of a piece of pure cryolite having crystals developed on one surface, systems of cracks were found diverging from the hitherto mentioned directions. In the section the direction of the cracks was seen to follow the crystallographic b-axis. The cracks were independent of the (100) twin lamellae present in the section and the plane of the cracks, clearly inclined against the plane of section, seemed to correspond to a (101) plane. Several of the crystals along the edge of the section had these cracks which, by the way, are more common in this part of the section. These cracks are clearly not connected with twin lamellae (they occur in optically homogeneous areas). Maybe it is a phenomenon like this that caused Krenner (1883) to suggest cleavage along (101). As similar cracks have not been observed on other sections of cryolite they are merely thought to reflect local response to a specific stress situation connected with the open crack onto the walls of which the cryolite crystals grew.

Acknowledgement. The large thin sections were produced by Mr. Ib H. Nielsen, Mineralogical Institute, Technical University of Denmark. I wish to thank him for the never failing care and interest with which he has carried out this most important piece of preparation work.

\section{Dansk sammendrag}

Udseendet af tvillinger $i$ forskellige grovkornede typer af kryolit fra Ivigtut belyses. Undersagelsen er baseret på $5 \mathrm{~cm}$ til $12 \mathrm{~cm}$ store tyndsnit af den rene, hvide, grovkornede kryolit, af tilsvarende grovkornet kryolit fra flusspatkryolit og fra en åre af kryolit, ren og helt sort, fra bjergarterne omkring selve kryolitmassen. De 7 love Bøggild $i 1911$ har pávist i ren kryolit, fandtes også i de fleste af de undersøgte prøver. I prøven fra flusspatkryolit viste det sig dog, at tvillinger efter (001) dominerede og $i$ kryoliten fra ăren var det [021] ${ }^{120}$, der dominerede billedet. Det almindelige indtryk fra undersøgelsen er, at alle tvillingdannelserne skyldes mekanisk pávirkning. Den karakteristiske afsondring er noje forbundet med tvillinglamellerne, hovedsagelig, som Bøggild (1911) meddeler, tvillinglameller efter [021] ${ }^{120}$ men også (110) (Bøggild 1913) og (001) som $i$ prøven fra flusspatkryolit, der her er undersøgt. Denne prøve indeholder også tegn på gentagne nyorienteringer af stykkets krystallografiske retninger, formentlig forårsaget af udefra kommende mekaniske påvirkninger.

\section{References}

Bøggild, O. B. 1905: Mineralogia Groenlandica. Meddr Grønland 32: $625 \mathrm{pp}$.

Bøggild, O. B. 1911: Krystalform og Tvillingdannelser hos Kryolit, Perovskit og Boracit. Meddr Gronland 50 (1): $85 \mathrm{pp}$.

Beggild, O. B. 1912: Krystalform und Zwillingsbildungen des Kryoliths, des Perowskits und des Boracits. Z. Krystallogr. 50: 349-429.

Bøggild, O. B. 1913: Beobachtungen über die Mineralien der Kryolithgruppe. Z. Krystallogr. 51: 591-613.

Bøggild, O. B. 1953: The Mineralogy of Greenland. Meddr Gronland 149 (3): $442 \mathrm{pp}$.

Donnay, I. D. H. 1952: Cryolite twinning. Am. Mineral. 37: 230-234.

Karup-Møller, S. and Hans Pauly, in press: Galena and associated minerals from the cryolite deposit at Ivigtut, South Greenland.

Krenner, J. A. 1883: Die Grönländischen Minerale der Kryolithgruppe. Math.-Nat. Ber. Ungarn 1: 1-24.

Oen Ing Soen and Hans Pauly 1967: A sulphide paragenesis with pyrrhotite and marcasite in the siderite cryolite ore of Ivigtut, South Greenland. Meddr Gronland 175 (5): $55 \mathrm{pp}$.

Pauly, Hans 1960: Paragenetic relations in the main cryolite ore of Ivigtut, South Greenland. N. Jb. Miner., Abh., Festband Ramdoht 94: 121-139.

Pauly, Hans 1974: Ivigtut cryolite deposit, SW-Greenland. In: M. Stemprok, editor, Metallization associated with acid magmatism (MAWAM), IGCP-Symposium MAWAM, Praha, Vol. 1 pp. 393-399.

Pauly, Hans 1977: Cryolite, chiolite and cryolithionite: Optical data redetermined. Bull. geol. Soc. Denmark 26: 95-101. 